This is an author produced version of a paper published in Biological Conservation. This paper has been peer-reviewed and is proof-corrected, but does not include the journal pagination.

Citation for the published paper:

Ranius, T., Jansson, N. (2000) The influence of forest regrowth, original canopy cover and tree size on saproxylic beetles associated with old oaks. Biological Conservation.

Volume: 95 Number: 1, pp 85-94.

http://dx.doi.org/10.1016/S0006-3207(00)00007-0

Access to the published version may require journal subscription. Published with permission from: Elsevier

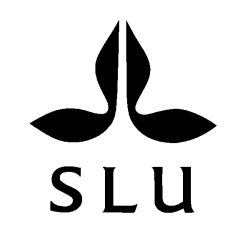

Epsilon Open Archive http://epsilon.slu.se 
Should be cited as:

Ranius, T. \& Jansson, N. (2000) The influence of forest regrowth, original canopy cover and tree size on saproxylic beetles associated with old oaks. Biological Conservation 95: 85-94

Available at: http://www.sciencedirect.com/science/journal/00063207

\section{The influence of forest regrowth, original canopy cover and tree size on saproxylic beetles associated with old oaks}

Thomas Ranius ${ }^{\text {a }}$, Nicklas Jansson ${ }^{\text {b }}$

${ }^{\text {a }}$ Lund University, Department of Zoology, Helgonav. 3, SE-223 62 Lund, Sweden

${ }^{\mathrm{b}}$ The County Administration board of Östergötland, Environmental Department, SE-581 86

Linköping, Sweden

Abstract

Abandoned management has caused many sites with free-standing, large oaks (Quercus robur) to become more shaded. This study shows how forest regrowth affects beetle species associated with old oaks in south-eastern Sweden. Beetles were trapped by pitfall traps placed in hollows and window traps placed near hollows in oak trunks in pasture woodlands. We assessed the influence of forest regrowth, tree size and original canopy cover on the species richness of saproxylic beetles (a total of 120 species identified) and the occurrence of 68 saproxylic beetle species in particular. Species richness was greatest in stands with large, free-standing trees. Large girth as well as low canopy cover increased frequency of occurrence for several species. Forest regrowth was found to be detrimental for many beetle species. As most localities with endangered beetles living in old oaks are small and isolated, ongoing management and the restoration of abandoned pasture woodlands should have a high priority in nature conservation.

Keywords: Saproxylic beetles; Quercus robur; Pasture woodland; Forest regrowth; Tree hollow; Microclimate 


\section{Introduction}

In Europe, old-growth temperate deciduous forests have declined to a very small fraction of their original extent (Hannah et al., 1995), and this has caused very old trees to be much more scarce. Up until the 19th century, old trees were also widespread in pasture woodlands (Kirby et al., 1995), but abandoned management and changes of land use have caused a severe reduction of these habitats (e.g. Nilsson, 1997a; Kirby and Watkins, 1998). Therefore, many species dependent on old deciduous trees have remnant distributions with small, isolated populations (e.g. Harding and Rose, 1986; Speight, 1989). One such group are beetles that have a restricted dispersal capacity and are dependent on hollow trees (Speight, 1989; McLean and Speight, 1993; Nilsson and Ericson, 1997). In Sweden, large oaks (Quercus robur) sustain the most diverse fauna of beetles associated with old trees (Palm, 1959). The largest oaks (in trunk diameter, not in height) have formerly grown more or less in the open in wooded meadows (mainly used for hay-making) and, more lately, in pasture woodlands (mainly used for grazing) (Eliasson and Nilsson, 2000). As agriculture has changed drastically in the last few decades, many pasture woodlands have been abandoned (Nilsson, 1997a), and this has caused the habitats containing sunexposed old trees to decrease, in favour of shadier woods. This might be detrimental to the beetle fauna, since it is generally held among entomologists that beetles associated with old oaks prefer sun-exposed trees (e.g. Palm, 1959; Gärdenfors and Baranowski, 1992). However, there is a lack of quantitative data to support this view (but see Ranius and Nilsson, 1997; Lott, 1999). The present study considers how current management, original canopy cover and tree size affect the frequency of saproxylic beetles in old, hollow oaks. The first aim was to examine how the frequency of occurrence of beetles relates to original canopy cover. We would expect that there are species preferring large, free-standing oaks, but is there also an assemblage of species associated with shadier woods? The second aim was to assess how the beetle fauna is influenced by forest regrowth and whether the beetles are affected indifferent ways depending on which microhabitat they are associated with. The third aim was to study the preference for characteristics of individual trees that could explain the difference in frequency of occurrence between stands. Are the higher frequencies in stands with large, free-standing trees a result of preference for large girths or for sun-exposure?

2. Study plots, material and methods

\subsection{Study plots}

This study was performed in one of the few remaining landscapes in Northern Europe with a high density of old oaks, which is situated in the province of Östergötland, south-eastern Sweden (Antonsson and Wadstein, 1991). Here, plots were studied in a $12 \times 16 \mathrm{~km}$ area with Bjärka-Säby as its centre ( $15 \mathrm{~km}$ south from Linköping, $58^{\circ} 16^{\prime} \mathrm{N}, 15^{\circ} 46^{\prime} \mathrm{E}$ ). We surveyed the beetle fauna of hollow oaks in 18 plots, each with an area of 0.5-8 ha. The plots were selected to obtain three groups of six plots differing in original canopy cover. The 'original cover' was assessed by measuring the canopy of 
mature and old trees, i.e. by ignoring the cover produced by young trees that had invaded former open woodland. Thus, six plots contained mainly originally free-standing oaks (vertical coverage of the canopy: 10-30\%), another six contained originally half-open pasture woodland (30-70\% coverage) and the remaining six contained originally closed pasture woodland (70-90\% coverage). Each category was subdivided so that three plots were still affected by grazing while the other three were regrown due to natural regeneration of deciduous trees. These young deciduous trees were 5-10 $\mathrm{m}$ high and mainly in dense stands, even though glades and patches with sparser canopy cover occured frequently. According to the category division above, the plots were characterized by two variables: ORIGINAL CANOPY COVER and FOREST REGROWTH. Moreover, for each tree with traps seven variables were estimated that might influence the results if they correlated with the two variables on the plot level (Table 1).

\subsection{Beetle trapping}

We set traps in and near hollows of oak trunks to survey saproxylic beetles living in old oaks, especially those associated with wood mould, but other saproxylic beetles associated with old oaks were also studied. Wood mould is fungi-infested loose wood in hollows, often with remains of bird nests and insect fragments. In each plot, we selected five living oaks with hollow trunks for trapping. The trees were chosen at random among those hollow trees where we were able to set traps. To be suitable for pitfall trapping, the entrance to the hollow had to be wide enough and not more than $7 \mathrm{~m}$ from the ground and the wood mould surface not too far from the entrance. In each tree, one pitfall trap and one window trap were set. The pitfall traps were plastic jars with a top diameter of $65 \mathrm{~mm}$, placed with the opening level with the wood mould in the hollows. Each window trap consisted of a $30 \times 40 \mathrm{~cm}$ wide transparent plastic plate with a tray underneath. Window traps were placed beside or in front of the entrance of the hollow. Glycol and water was used as preservative in all traps and detergent added to eliminate surface tension. The traps were placed in the trees 6-13 May and removed 8-16 August in 1994 and were examined every third week. All saproxylic beetle species can be caught within this period, even though a few individuals are active earlier and later than this (own obs.). This study includes beetles living in dead wood, saproxylic fungi, wood mould and animal nests in mature and old oaks. The beetles were identified by Nicklas Jansson, except Ampedus and Cryptophagidae which were identified by Rickard Andersson (formerly Baranowski). The following taxa include some saproxylic species, but they were not analyzed as they are difficult to identify or regarded as being of limited interest for this study: Anaspidae, Dasytinae, Euglenidae, Latridiinae, Nitudulidae, Ptilidae, Staphylinidae (except Staphylininae and Omaliinae) and Throscidae. The beetle species were divided into groups with regard to their microhabitat in trees (Table 2). The microhabitats of each species were obtained by consulting Swedish entomologists, in particular Rickard Andersson (pers. comm.), but also Bengt Ehnström (pers. comm.), Palm (1959) and our own observations. 


\subsection{Statistical analyses}

The number of trees per plot with each species present was studied in relation to ORIGINAL CANOPY COVER and FOREST REGROWTH using analysis of covariance. The total number of species per tree, and for each of the six microhabitat groups were summed for each plot and analyzed similarly. Characteristics of trees with traps were estimated (Table 1) and analysis of their correlation with ORIGINAL CANOPY COVER and FOREST REGROWTH revealed three statistically significant relations: TRUNK DIAMETER was much greater in plots with low ORIGINAL CANOPY COVER (Spearman coefficient, $\mathrm{C}=-0.767, \mathrm{P}<0.001$ ), and SURROUNDING COVER increased with increasing ORIGINAL CANOPY COVER $(\mathrm{C}=0.381, \mathrm{P}<0.001)$ and was higher in plots with FOREST REGROWTH $(\mathrm{C}=0.326, \mathrm{P}=0.002)$. TRUNK DIAMETER and SURROUNDING COVER may therefore influence the correlation between species occurrence and characteristics of plots. Consequently, the presence (1) and absence (0) of each species were analyzed in relation to these two variables with multiple logistic regression (Hosmer and Lemeshow, 1989), and number of species in different microhabitats per tree were analyzed with multiple linear regression. The correlation between species richness and SURROUNDING COVER and TRUNK DIAMETER was further explored by comparing the number of species in trees divided into categories varying in these characteristics. Possible differences in occurrence patterns between redlisted and other species were controlled for by analyzing correlations not only with total number of species, but also with these two groups separately. All statistical analyses were carried out by use of SPSS 6.1.

\subsection{Weather}

The mean temperature was lower than normal in May and June, but higher than normal in July and August (Temperature, May, June, July, August 1994: 9.8, 13.4, 20.5, 16.7 C, mean 1960-1990: 10.5, 15.0, 16.2 and $15.3^{\circ} \mathrm{C}$, respectively. Data from SMHI, Meteorological station of Malmslätt, $20 \mathrm{~km}$ from Bjärka-Säby).

\section{Results}

\subsection{Species richness}

In total, we found and indentified 120 saproxylic beetle species associated with mature or old oaks (Table 2). Among these species, $40 \%$ were on the Swedish red list. The number of identified beetle species per plot (five trees) varied between 36 and 58 (mean=47.4, S.D.=7.5) and per tree between 7 and 34 (mean=20.0, S.D.=6.3). We considered that a species must be present in at least five trees out of the 90 in order to analyze its occurrence in particular. This was the case for 68 species (Table 3), and among these, $41 \%$ were on the Swedish red list.

3.2. Plot differences: canopy cover and forest regrowth 
The frequency of occurrence of saproxylic beetle species was higher in plots that were originally open (low ORIGINAL CANOPY COVER) and were still grazed (FOREST REGROWTH=0) (Table 4). Beetles associated with fruiting bodies of saproxylic fungi were the only group that showed a slight tendency to positive correlation with FOREST REGROWTH. Frequency of presence increased significantly with ORIGINAL CANOPY COVER for one species and decreased for four species. Furthermore, frequency of presence was lower in plots with FOREST REGROWTH for 10 species, whereas it was higher for one (Table 3). There was no assemblage of species associated with originally shadier forest. One single species - Hypebaeus flavipes - had greater frequency of occurrence in stands with higher original canopy cover. This seemed to be due to its preference for thinner trunks, as the species in the analysis at the per tree level was associated with thinner trunks and an open surrounding (Table 3). STAND SIZE was positively correlated with ORIGINAL CANOPY COVER ( $\mathrm{P}=0.007)$ so an analysis of covariance was made between the number of species per plot in relation to STAND SIZE, ORIGINAL CANOPY COVER and FOREST REGROWTH. Since no significant effect was found we were satisfied that species richness was not affected by the number of large hollow oaks around our sample plots.

\subsection{Tree effects: trunk diameter and surrounding cover}

Low SURROUNDING COVER and large TRUNK DIAMETER were similar in importance for the frequency of occurrence of species (Tables 3 and 5). Species predominantly occurring in originally more open stands were affected both by surrounding cover and trunk diameter; of the four species significantly preferring originally low canopy cover, one preferred sunexposed trees and three preferred large girths (Table 3). Free-standing trees sustained higher species richness than trees situated in half-open or shaded conditions, whereas the difference between the two latter categories was small. Species richness was lower especially for trees with the thinnest trunks, whereas the difference was smaller between trees of intermediate and large girths (Table 6). Beetles associated with hollows and fruiting bodies of saproxylic fungi obtained the strongest positive correlation with large girths, but beetles in all microhabitats showed this trend. In general, red-listed species showed the same trends in their occurrence patterns as other species (Tables 4 and 6).

\section{Discussion}

\subsection{Characteristics on plot and tree level}

Grazed stands contained more saproxylic beetle species (Tables 3 and 4), probably because increased sun exposure makes the microclimate warmer. In grazed land, the habitat is more open not just because of grazing itself, but also because shrubs and young trees arecut to increase grass growth. The group of beetles that were most negatively affected by forest regrowth, were those associated with 
animal nests (Table 4). This suggests that the preference for sun exposure for some species could also be because bird nests in tree hollows are more frequent in open areas. Due to better food availability for birds in open habitats, birds occupy a higher proportion of hollows near agricultural land than inside forests (Johnsson et al., 1993). Beetles associated with fruiting bodies of saproxylic fungi (group 4) prefer trees with large girths and a surrounding with a dense canopy cover (Table 5). One explanation could be that such trunks benefit saproxylic fungi by maintaining better moisture conditions, whereas another possibility is that such trees provide more entries able for the fungi to colonize. Both these conditions are important for the colonization of saproxylic fungi (Rayner and Boddy, 1988). The girths of the trunks are not affected by forest regrowth in the last few decades, but the trunks are thinner in originally shadier forests. Therefore, large oaks subject to forest regrowth might be the most suitable for beetles associated with fruiting bodies of saproxylic fungi. The preference for sun-exposed oaks has been considered by several Swedish entomologists (Palm, 1959; Gärdenfors and Baranowski, 1992; Jonsell et al., 1998) and is currently studied in Britain (Alexander, 1999; Lott, 1999) but most European studies on saproxylic beetles do not discuss any such preference (e.g. Dajoz, 1980; Harding and Rose, 1986; Speight, 1989; Hyman, 1992). Among the Swedish studies, only Palm (1959) records the habitat preference for single species and allows comparisons with the present study. The proportion of species preferring sun exposure and shade according to Palm (1959) is consistent with the present study, but his conclusions regarding individual species is partly contradictory with ours (Table 7). He studied more tree species in a broader climatic range, which may explain the differences in habitat preference compared to our study. It is impossible to look closer at this result, however, because he did not include quantitative data in his report. Studies on single species that include quantitative estimates are in better agreement with the present study (Osmoderma eremita: Ranius and Nilsson, 1997; Grynocharis oblonga: Nilsson, 1997b). Consequently, conclusions about habitat preferences must be based on quantitative analysis of data, not simply observations, so that the generality of the conclusions can be determined and further tested. Only then will we gain firm knowledge of the habitat characteristics favoured by saproxylic beetles. It is possible that the occurrence of some species are weakly correlated with the studied variables of sun exposure, that are affected by management, but still thespecies prefer a warm microclimate. A study on Osmoderma eremita showed that the frequency of occurrence is higher in hollows with the entrance facing south or west (Ranius and Nilsson, 1997). The orientation of the entrance is also a characteristic that affects sun exposure and microclimate (Kelner-Pillault, 1974), although the association between occurrence of O. eremita and canopy cover was rather weak in that study, as well as the present study. As the activity of beetles generally increases with increased temperature (e.g. Chiverton, 1988; Luff, 1982), catchability might be higher in sun-exposed trees. However, this study was performed in a summer with warmer weather than average, and therefore we think it was warm enough for all species to be catchable this year, even in trees with a cooler microclimate. The study area is situated near the northern distribution limit for many of the studied species, and the climate is cooler there than in the centre of their 
distribution range in Europe. According to Martin (1989), beetles living in hollow trees prefer sunexposed trees when near the northern limits of their distribution, but further south they occupy shadier habitats as well. Studies on butterflies in Britain and France have shown that in the cooler climate of Britain, butterflies are confined to habitats with warmer microclimates than in France (Thomas, 1993). Thus, the species in this study might be less strongly associated with open habitats further south in Europe, but we know of no relevant studies. Presently, some saproxylic beetles are confined to large free-standing oaks, which are a mainly man-made habitat. How could these species exist before man began managing the landscape? One explanation could be that the beetles were capable of occupying cooler microhabitats in the past because of warmer climates in general, in congruence with Thomas' (1993) hypothesis regarding thermophilous butterflies in Britain. Beetles associated with old oaks probably increased their range and reached their highest abundances in Scandinavia in the mid Holocene (8000-4000 B.P.) because broadleaf deciduous forests was much more extensive then than today (Huntley, 1988). As it was a few degrees warmer in the summer at that time than today (Huntley and Prentice, 1988), saproxylic beetles might were able to live even in dense forests then. Possibly, when the climate cooled, some species were able to sustain themselves exclusively in habitats with warmer microclimate created by man. It is also possible, however, that the species are originally adapted to warmer microhabitats which occurred even in primary woodlands (Warren and Key, 1991). Sun-exposed sites occur naturally in precipices (Ek et al., 1995), along rivers and sea-shores. Large glades could also be a result of grazing by large herbivores (Owen-Smith, 1987) and catastrophic events (Warren and Key, 1991). Beetles may prefer larger trunks because the larger the girth, the more stable the microclimate. Alternatively the stage of decay of a trunk may influence its suitability. When a hollow tree ages, the trunk diameter increases, but other characteristics of the tree also change, for example, the entrance size and volume of the hollow increase (Kelner-Pillault, 1974). This study suggests that most species prefer trees of intermediate or late stages of the successional decay of living, hollow trunks.

\subsection{Conclusions for nature conservation}

Plantations and natural regeneration of formerly open pasture woodlands cause existing old trees to die prematurely because of shading and competition for soil moisture and nutrients (Key and Ball, 1993; Alexander et al., 1996). We found that some saproxylic beetle species are also harmed by forest regrowth. There is a tendency for red-listed species to be more negatively affected by cessation of grazing than other beetle species (Table 4). Thus, to preserve the rarer saproxylic beetle fauna it is important to continue the management of areas with old oaks. This study shows that even where management has been abandoned in the last few decades most species still occur, albeit many of them in lower abundance. This is partly because the sites are heterogenous, and therefore some oaks remain sunexposed for a few decades even without management. Such sites should be restored, to delay the deaths of the trees and decrease risk of extinction of endangered beetle species. Restoration of regrown 
sites should include cutting of shrubs and young trees and resumption of grazing. The cutting should be done with care, as dramatic changes of the microclimate could lead to death of the oaks (Alexander et al., 1996). Another problem is that Formica spp. often colonize hollow oaks if the surrounding canopy cover suddenly decrease (own obs.). We do not know the consequences of the presence of these ants, but there is circumstantial evidence that suggests they have a great impact as predators on forest invertebrates, including saproxylic beetles (Gösswald, 1990). If grazing has been abandoned for several decades, young trees should be cut in the immediate surrounding of the old trees, but usually not in other parts of the site. On the other hand, in sites where grazing has ceased more recently, a complete restoration including cutting of most shrubs and young trees could be done in one step. When the forest regrowth is in intermediate successional stages, fast-growing tree species (in our study plots ash (Fraxinus excelsior), aspen (Populus tremula) and birch (Betula verrucosa)) should be removed first, as these are the worst competitors for the old oaks. In many other sites in Sweden, the old oaks are surrounded by planted Norway spruce (Picea abies), and these must also be cut down. Slow-growing tree species (like younger oaks) could be removed later or be saved. It is usually not appropriate to cut down mature oaks, as it is desirable to have many oaks which can take over the role as hollow trees in the future. At many sites the number of hollow oaks are very small and there are gaps in the generation structure (Britain: Key and Ball, 1993; Sweden: own obs., e.g. Jansson and Tingvall, 1998). In small stands, the number of old trees needs to increase if the beetle fauna is to be sustained in the long run, as stand size (Ranius, 2000) and historical continuity (Nilsson and Baranowski, 1997) have been found to be important factors for the occurrence of some rare saproxylic beetles associated with tree hollows. Where there are problems with age gaps, decay could be initiated prematurely, by injuring younger trees. For example chain-saws or explosives could be used to produce shattered trunks or branch stumps which could initiate the formation of trunk hollows (Key and Ball, 1993; Alexander et al., 1996). The effects of such a treatment might be similar to that of the traditional use of oaks. There are Swedish documents from the 18th century indicating that rot holes commonly arose in oaks when branches were cut down (Eliasson and Nilsson, 2000). There are a few species that tend to increase when management ceases, mostly species associated with fruiting bodies of saproxylic fungi. Even in a grazed pasture woodland, however, there are often denser patches which make survival possible even for these species. Moreover, among the species of the present study, those associated with fruiting bodies of saproxylic fungi have fewer species on the red list compared to other groups of saproxylic beetles (Table 2).

\section{Acknowledgements}

Kjell Antonsson provided useful advice regarding the field work. Rickard Andersson, Stig Lundberg and Kjell Antonsson helped us with the identification of beetle species. Sven G. Nilsson (working within SUFOR), Per Douwes, Lyn Raffan and Örjan Östman have given valuable comments on the 
manuscript. The study was economically supported by the Swedish Environmental Protection Agency and the The County Administration board of Östergötland.

\section{References}

Alexander, K., 1999. Should deadwood be left in sun or shade? British Wildlife 10, 342.

Alexander, K.N.A., Green, E.E., Key, R., 1996. The management of over mature tree populations for nature conservation - the basic guidelines. In: Read, H.J. (Ed.), Pollard and Veteran Tree Management II. Corporation of London, Burnham Beeches, pp. 122-135.

Antonsson, K., Wadstein, M., 1991. Eklandskapet. En naturinventering av hagar och lövskogar i Eklandskapet S. om Linköping. Länsstyrelsen i Östergötlands län, Linköping (in Swedish).

Chiverton, P.A., 1988. Searching behaviour and cereal aphid consumption by Bembidion lampros and Pterostichus cupreus, in relation to temperature and prey density. Entomologia Experimentalis et Applicata 47, 173-182.

Dajoz, R., 1980. Écologie des Insectes Forestièrs. Gauthier-Villars, Paris.

Ehnström, B., Gärdenfors, U., Lindelöw, Å ., 1993. Rödlistade evertebrater i Sverige 1993 (Swedish Red List of Invertebrates 1993). Databanken för hotade arter, Uppsala (in Swedish, English abstract).

Ek, T., Wadstein, M., Johannesson, J., 1995. Varifrån kommer lavar knutna till gamla ekar? (What is the origin of the lichen flora of old oaks?). Svensk Botanisk Tidskrift 89, 335-343, (in Swedish, English abstract).

Eliasson, P., Nilsson, S.G., in press. Rättat efter Skogarnes aftagande -en miljöhistorisk undersökning av den svenska eken under 1700- och 1800-talen. (The Swedish oak during the eighteenth and nineteenth centuries $Đ$ aspects of quantities, qualities and biodiversity). Bebyggelsehistorisk tidskrift (in Swedish, English abstract).

Gärdenfors, U., Baranowski, R., 1992. Skalbaggar anpassade till öppna respektive slutna ädellövskogar föredrar olika trädslag [Beetles living in open forests prefer different tree species than those living in dense forests]. Entomologisk Tidskrift 113, 1-11, (in Swedish, English abstract).

Gösswald, K., 1990. Die Waldameise. Band 2 Die Waldameise im Ökosystem Wald, ihr Nutzen und ihre Hege. AULA-Verlag, Wiesbaden.

Hannah, L., Carr, J.L., Lankerani, A., 1995. Human disturbance and natural habitat: a biome level analysis of a global data set. Biodiversity and Conservation 2, 128-155.

Harding, P.T., Rose, F., 1986. Pasture-Woodlands in Lowland Britain. A Review of their Importance for Wildlife Conservation. Institute of Terrestrial Ecology, Huntingdon.

Hosmer, D.W., Lemeshow, S., 1989. Applied Logistic Regression. John Wiley and Sons, New York. 
Huntley, B., 1988. Section III. Glacial and holocene vegetation history - 20 ky to present. 1. Europe.. In: Huntley, B., Webb, T. (Eds.), Vegetation History. Handbook of Vegetation Science. Vol. 7. Kluwer Academic Publishers, Dordrecht, pp. 341-383.

Huntley, B., Prentice, I.C., 1988. July temperatures in Europe from pollen data, 6000 years before present. Science 241, 687-690.

Hyman, P.S., 1992. UK Nature Conservation No. 3: A Review of the Scarce and Threatened Coleoptera of Great Britain. The UK Joint Nature Conservation Commitee, Peterborough.

Jansson, N., Tingvall, A., 1998. Skötselplan för Halltorps naturreservat. Länsstyrelsen i Kalmar län, Kalmar (in Swedish).

Johnsson, K., Nilsson, S.G., Tjernberg, M., 1993. Characteristics and utilization of old black woodpecker Dryocopus martius holes by hole-nesting species. Ibis 135, 410-416.

Jonsell, M., Weslien, J., Ehnström, B., 1998. Substrate requirements of red-listed saproxylic invertebrates in Sweden. Biodiversity and Conservation 7, 749-764.

Kelner-Pillault, S., 1974. Étude écologique du peuplement entomologique des terraux d'arbres creux (chataigners et saules). Bulletin d'Ecologie 5, 123-156.

Key, R.S., Ball, S.G., 1993. Positive management for saproxylic invertebrates. In: K.J. Kirby, C.M. Drake (Eds.). Dead Wood Matters: The Ecology and Conservation of Saproxylic Invertebrates in Britain. English Nature Science No. 7, pp. 89-105.

Kirby, K.J., Watkins, C. (Eds.), 1998. The Ecological History of European Forests. CAB International, Oxon. Kirby, K.J., Thomas, R.C., Key, R.S., McLean, I.F.G., 1995. Pasture woodland and its conservation in Britain. Biological Journal of the Linnean Society (Suppl.) 56, 135-153.

Lott, D., 1999. A comparison of saproxylic beetle assemblages occurring under two different management regimes in Sherwood Forest. Naturalist 124, 67-74.

Luff, M.L., 1982. Population dynamics of Carabidae. Annals of Applied Biology 101, 164-170. Lundberg, S., 1995. Catalogus Coleopterorum Sueciae. Naturhistoriska. Riksmuseet, Stockholm.

Martin, O., 1989. Smældere (Coleptera, Elateridae) fra gammel løvskov i Danmark (Click beetles (Coleptera, Elateridae) from old deciduous forests in Denmark). Entomologiske Meddelelser 57, 1107 (in Danish, English abstract).

McLean, I.F.G., Speight, M.C.D., 1993. Saproxylic invertebrates - the European context. In: K.J. Kirby, C.M. Drake (Eds.). Dead Wood Matters: The Ecology and Conservation of Saproxylic Invertebrates in Britain. English Nature Science No. 7, pp. 21-32.

Nilsson, S.G., 1997a. Forests in the temperate-boreal transition: natural and man-made features. Ecological Bulletins 46, 61-71.

Nilsson, S.G., 1997b. Mörkbaggen Grynocharis oblonga en specialiserad vedskalbagge med reliktutbredning [Grynocharis oblonga L. (Coleoptera: Trogositidae) - a specialized wood 
beetle with a relict distribution]. Entomologisk Tidskrift 118, 1-9, (in Swedish, English abstract).

Nilsson, S.G., Baranowski, R., 1997. Habitat predictability and the occurrence of wood beetles in oldgrowth beech forests. Ecography 20, 491-498.

Nilsson, S.G., Ericson, L., 1997. Conservation of plant and animal populations in theory and practice. Ecological Bulletins 46, 117-139.

Palm, T., 1959. Die Holzund Rindenkäfer der Süd- und Mittelschwedischen Laubbäume (The wood and bark coleoptera of deciduous trees in southern and central Sweden). Opuscula Entomologica Supplementum XVI (in German, English Summary).

Owen-Smith, N., 1987. Pleistocene extinctions: the pivotal role of megaherbivores. Paleobiology 13, 351-362.

Ranius, T., 2000. Minimum viable metapopulation size of a beetle, Osmoderma eremita, living in tree hollows. Animal Conservation 3, 37-43.

Ranius, T., Nilsson, S.G., 1997. Habitat of Osmoderma eremita Scop. (Coleoptera: Scarabaeidae), a beetle living in hollow trees. Journal of Insect Conservation 1, 193-204.

Rayner, A.D.M., Boddy, L., 1988. Fungal Decomposition of Wood: Its Biology and Ecology. John Wiley and Sons, Chichester.

Speight, M.C.D., 1989. Saproxylic Invertebrates and their Conservation. Council of Europe, Strasbourg.

Thomas, J.A., 1993. Holocene climate changes and warm man-made refugia may explain why a sixth of British butterflies possess unnatural early-successional habitats. Ecography 16, 278-284. Warren, M.S., Key, R.S., 1991. Woodlands: past, present and potential for insects. In: Collins, N.M., Thomas, J.A. (Eds.), The Conservation of Insects and their Habitats. Academic Press, London, pp. 155-211. 
Table 1

Description of estimated variables

Name

Description

Variables of each plot

ORIGINAL CANOPY COVER Vertical coverage of the canopy $(10-30 \%=0,30-70 \%=1,70-90 \%=2)$ (continuous)

FOREST REGROWTH If the plot is still managed by grazing $(=0)$ or regrown $(=1)$ (categorical)

STANDARD SIZE The stand size, divided into two categories: small $(=0)$ or large $(=1)$, with 50 hollow oaks within a radius of $1 \mathrm{~km}$ as a limit

Name of each sampled tree hollow

AMOUNT OF WOOD MOULD The amount of wood mould, divided into two categories: small $(=0)$

AREA OF ENTRANCE or large $(=1)$ amounts, with about $10 l$ as a limit (categorical)

SURROUNDING COVER

Area of the entrance to the hollow ( $\mathrm{cm} 2$ ) (continuous)

If the tree is situated in an open, half open or shaded surrounding, i.e. whether the vertical projection of foliage in the surrounding of the tree is $<25 \%$ (free-standing=0), $25-75 \%$ (half-open=1) or $>75 \%$ ( shaded $=2$ ) (continuous)

DIRECTION (SUNSHINE) The direction of the entrance in relation to the sun (value increasing with increased nearness to the most sun exposed compass direction: $\mathrm{NE}=1, \mathrm{~N}$ or $\mathrm{E}=2, \mathrm{NW}$ or $\mathrm{SE}=3, \mathrm{~W}$ or $\mathrm{S}=4, \mathrm{SW}=5$ ) (continuous)

DIRECTION (UPWARDS) If the entrance is directed more or less vertically $(=0)$ or horizontally $(=1)$ (categorical)

HEIGHT OF ENTRANCE TRUNK DIAMETER The height of the entrance above the ground $(\mathrm{m})$ (continuous) Trunk diameter of the tree at $1.3 \mathrm{~m}$ height $(\mathrm{m})$ (continuous) 
Table 2

Beetle species trapped and determined in this study ${ }^{\mathrm{a}}$

1. Rotten wood in any part of the trunks, even on the outside of the trunk

Alosterna tabacicolor Ampedus balteatus Ampedus nigroflavus R Ampedus pomorum Calambus bipustulatus $\mathrm{R}$ Cerylon ferrugineum

Cerylon histeroides

Cis fagi

Cryptophagus badius

Cryptophagus scanicus

Ctesias serra

Dorcatoma chrysomelina

Dorcatoma flavicornis $\mathrm{R}$

Euplectus piceus

Euplectus punctatus

Grynocharis oblonga $\mathrm{R}$

Hypebaeus flavipes R

Hypulus quercinus $R$

Malachius bipustulatus

Megatoma undata

Melanotes castanipes

Melanotes erythropus

Mycetaea subterranea

Mycetochara flavipes

Mycetochara linearis

Mycetophagus piceus $\mathrm{R}$

Paromalus flavicornis

Ptinus rufipes

Rhyncolus ater

Rhyncolus sculpturatus

Sinodendron cylindricum

Tillus elongatus $\mathrm{R}$

Trichoceble memnonia

Uloma culinaris $\mathrm{R}$

Xyletinus longitarsus $\mathrm{R}$

Xyletinus pectinatus $\mathrm{R}$

2. Rotten wood in trunks, exclusively from the inside, in hollows. Not

associated with animal nests

Allecula morio R

Ampedus cardinalis $\mathrm{R}$

Ampedus hjorti R
Cryptophagus confusus $\mathrm{R}$

Cryptophagus labilis

Cryptophagus populi $\mathrm{R}$

Cryptophagus quercinus $R$

Dendrophilus punctatus

Elater ferrugineus R

Euplectus bescidicus $\mathrm{R}$

Euplectus karsteni

Euplectus nanus

Gnorimus nobilis R

Korynetes coeruleus

Locola marmorata $\mathrm{R}$

Mycetochara axillaris $\mathrm{R}$

Mycetochara humeralis $\mathrm{R}$

Mycetophagus populi $\mathrm{R}$

Osmoderma eremita $R$

Pentaphyllus testaceus $\mathbf{R}$

Plectophloeus nitidus $R$

Plegaderus caesus $\mathrm{R}$

Prionychus ater $\mathrm{R}$

Procraerus tibialis $\mathrm{R}$

Pseudocistela ceramboides

R

Ptinus fur

Ptinus subpilosus

Rhizophagus cribratus $\mathrm{R}$

Stenichnus godarti

Tenebrio opacus $\mathrm{R}$

3. Animal nests in tree

hollows

Anthrenus museorum

Anthrenus scrophulariae

Atomario morio

Attagenus pellio

Batrisodes adnexus R

Batrisodes venustus

Cryptophagus micaceus $\mathrm{R}$

Dermestes lardarius

Hapalarea pygmaea $R$

Globicornis nigripes $\mathrm{R}$

Gnathoncus buyssoni

Gnathoncus nidorum $\mathrm{R}$

Nemadus colonoides $\mathrm{R}$

Palorus depressus

Quedius brevicornis

Quedius cruentus

Quedius scitus

Scraptia fuscula $\mathrm{R}$

Scydmaenus hellwigi
Tenebrio molitor

Trox scaber

Velleius dilatatus $\mathrm{R}$

4. Fruiting bodies of

saproxylic fungi

Atomaria alpina $\mathrm{R}$

Atomaria bella

Atomaria umbrina

Cryptophagus dentatus

Dacne bipustulata

Diaperis boleti

Eledona agricola

Endomychus coccineus

Hallomenus binotatus

Mycetina cruciata

Mycetophagus

quadriguttatus $\mathrm{R}$

Orchesia micans

Orchesia undulata

Triplax aenea

Triplax russica

5. Dead, dry wood in trunks

Agrilus biguttatus R

Anobium nitidum

Anobium rufipes

Corticeus fasciatus $\mathrm{R}$

Gastrallus immarginatus $\mathrm{R}$

Hadrobregmus pertinax

Hedobia imperialis

Lyctus linearis

Lymexylon navale $\mathrm{R}$

Phymatodes testaceus

Xestobium rufovillosum

6. Branches of old oaks

Agrilus laticornis

Agrilus sulcicollis

Agrilus viridis

Conopalpus testaceus

Grammoptera ustulata $\mathrm{R}$

Leiopus nebulosus

${ }^{a}$ Division in ecological groups according to their microhabitat. Taxonomy according to Lundberg (1995). Red-listed species (Ehnström et al., 1993) are marked with an $\mathrm{R}$. 
Table 3

Analysis of occurrence of 68 saproxylic beetle species ${ }^{\mathrm{a}}$

Species

Agrilus sulcicollis

Allecula morio

Alosterna tabacicolor

Ampedus balteatus

Ampedus cardinalis

Ampedus hjorti

Anobium nitidum

Anobium rufipes

Anthrenus museorum

Anthrenus scrophulariae

Atomaria morio

Cerylon ferrugineum

Cerylon histeroides

Conopalpus testaceus

Cryptophagus badius

Cryptophagus dentatus

Cryptophagus micaceus

Cryptophagus quercinus

Cryptophagus scanicus

Ctesias serra

Dendrophilus punctatus

Diaperis boleti

Dorcatoma chrysomelina

Dorcatoma flavicornis

Elater ferrugineus

Eledona agricola

Euplectus karsteni

Gastrallus immarginatus

Globicornis rufitarsis

Gnathoncus buyssoni/nan

Grammoptera ustulata

Grynocharis oblonga

Hapalarea pygmaea

Hypebaeus flavipes

Leiopus nebulosus

Liocola marmorata

Lymexylon navale

Megatoma undata

Melanotus castanipes

Melanotus erythropus

Mycetochara humeralis

Mycetochara linearis

Mycetophagus piceus

Nemadus colonoides

Orchesia micans
Mean

\subsection{9}

2.22

1.11

0.67

0.94

0.89

0.78

0.28

1.33

0.39

2.00

0.44

1.33

1.06

1.39

1.06

3.00

1.00

3.72

3.78

2.06

1.33

3.56

2.50

0.44

0.39

0.67

1.50

1.00

0.33

0.28

0.67

1.00

0.39

0.72

0.72

1.39

0.72

0.67

1.33

1.50

3.11

0.44

0.33
Analysis of covariance

(A)

0.083

$-0.750$

$-0.167$

$-0.667 * * *$

$-0.167$

$-0.250$

$-0.250$

0.000

$-0.250$

$-0.417$

$-0.167$

0.000

$-0.083$

$-1.000 *$

$-0.083$

0.167

$-0.250$

$-0.250$

0.000

$-0.333$

0.333

$-0.167$

$-0.417$

0.000

0.000

$-0.083$

0.000

0.500

$-0.083$

610.333

$-0.250$

$-0.417 * *$

$-0.500$

0.667 *

0.083

0.000

$-0.083$

$-0.333$

0.000

$-0.167$

0.500

$-0.167$

0.583

$-0.250$

$-0.250$
(B)

$-0.111$

$-1.333^{*}$

0.667

$-0.667 *$

$-0.333$

$-0.222$

$-0.444$

0.111

$-0.778$

$-0.333$

$-0.222$

0.444

0.222

$-0.778$

$-0.111$

$1.000 *$

0.222

0.000

$-0.111$

$-0.889$

$-0.556$

$-0.667$

$-0.444$

$-1.444 *$

0.444

0.333

$-0.111$

0.111

$1.500 * * *$

$-0.556$

0.000

$-0.111$

0.667

$-0.222$

$-0.111$

0.333

0.111

$-0.556$

0.778

$-0.889$

0.667

0.333

$-0.667$

0.222

0.000
Logistic regression

(C) (D)

$\begin{array}{ll}-1.02 & -0.89\end{array}$

$-1.31 * * * \quad 0.58$

$-0.29 \quad 0.08$

$-0.40 \quad 1.53 *$

$0.29 \quad 0.60$

$-0.12 \quad 0.81$
-0.25

$-0.25 \quad 0.66$

$\begin{array}{ll}-0.61 & 0.27\end{array}$

$\begin{array}{ll}-0.58 & 0.76\end{array}$

$-1.42 * \quad 0.18$

$0.07 \quad 0.09$

$0.66 \quad 0.48$

$-0.23 \quad-0.37$

$-1.16^{* * *} \quad 0.26$

$0.64 \quad 1.46^{*}$

$0.86 \quad 0.70$

$0.94 * * \quad 0.83$

$0.32 \quad 0.93$

$0.10 \quad 0.23$

$\begin{array}{ll}-0.65 & 0.33\end{array}$

$\begin{array}{ll}0.10 & -0.59\end{array}$

$\begin{array}{ll}0.009 & 0.47\end{array}$

$0.19 \quad 1.05$

$-0.48 \quad-0.67$

$-0.14 \quad 1.10$

$-0.69 \quad-0.60$

$\begin{array}{ll}-0.09 & 0.69\end{array}$

$-0.44 \quad-1.38 *$

$-0.61 \quad 0.005$

$-0.22 \quad-1.11^{*}$

$-0.73 \quad 0.96$

$-1.06 \quad 3.24^{* *}$

$0.29 \quad 1.94 * *$

$-0.77 * \quad-2.02 * *$

$1.20 \quad 0.15$

$-0.39 \quad-0.91$

$\begin{array}{ll}-0.26 & 0.59\end{array}$

$\begin{array}{ll}-0.53 & 0.51\end{array}$

$\begin{array}{ll}0.81 & 0.59\end{array}$

$-0.20 \quad 0.07$

$-0.08 \quad-0.61$

$-0.64 * \quad-0.49$

$-0.15 \quad-0.76$

$0.56 \quad-0.21$

$-1.31 * \quad 1.69$ 


$\begin{array}{llllll}\text { Osmoderma eremita } & 1.56 & -0.083 & -0.444 & -0.14 & -0.04 \\ \text { Paromalus flavicornis } & 0.33 & -0.167 & 0.444 & 1.09 & 2.59^{*} \\ \text { Pentaphyllus testaceus } & 0.28 & 0.083 & 0.111 & -1.33^{*} & -1.33 \\ \text { Phymatodes testaceus } & 1.00 & -0.083 & 0.000 & 0.39 & 0.70 \\ \text { Plegaderus caesus } & 0.44 & 0.083 & -0.667^{*} & -0.52 & -0.97 \\ \text { Prionychus ater } & 2.44 & -0.500 & -0.667 & -0.40 & 0.58 \\ \text { Procraerus tibialis } & 0.67 & 0.167 & -0.889^{*} & -0.41 & -0.30 \\ \text { Pseudocistela ceramboides } & 1.78 & -0.083 & -0.444 & -0.06 & -0.16 \\ \text { Ptinus fur } & 4.06 & -0.417 & -1.000^{*} & -0.36 & 1.82^{*} \\ \text { Ptinus rufipes } & 2.89 & -0.333 & 0.222 & 0.03 & 0.38 \\ \text { Ptinus subpilosus } & 4.78 & 0.167 & 0.000 & 2.04 * & 0.32 \\ \text { Quedius brevicornis } & 0.67 & 0.167 & 0.000 & -0.65 & -1.59 \\ \text { Quedius cruentus } & 0.61 & -0.333 & -0.333 & 0.32 & 0.05 \\ \text { Quedius scitus } & 0.56 & 0.167 & 0.222 & 0.43 & 0.32 \\ \text { Rhyncolus ater } & 0.44 & -0.250 & 0.000 & -0.25 & 0.50 \\ \text { Scraptia fuscula } & 2.50 & 0.167 & -2.333^{* *} & -0.40 & -0.38 \\ \text { Tenebrio molitor } & 1.06 & -0.167 & -1.000^{*} & -0.71 * & 0.71 \\ \text { Tenebrio opacus } & 0.61 & -0.667 * & -0.667 & -0.67 & 2.21^{* *} \\ \text { Tillus elongatus } & 0.50 & 0.333 & -0.111 & -0.54 & -1.06 \\ \text { Trichoceble memnonia } & 2.33 & 0.000 & -0.667 & 0.15 & 1.08^{*} \\ \text { Trox scaber } & 1.39 & -0.500 & -1.444^{*} & -0.64 * & -0.40 \\ \text { Velleius dilatatus } & 2.17 & 0.000 & -0.111 & 0.15 & -0.07 \\ \text { Xestobium rufovillosum } & 3.11 & 0.167 & -0.889 & -0.30 & 0.12\end{array}$

${ }^{\text {a }}$ Column 1 gives mean number of trees per plot with species present (five trees sampled in each plot). Columns 2 and 3 give analysis of covariance between this mean number and FOREST REGROWTH using ORIGINAL CANOPY COVER as covariate: $\mathrm{A}=$ coefficient of covariate, $\mathrm{B}=$ difference in mean number of trees in plots grazed and ungrazed ( $\mathrm{n}=18$ plots). Columns 4 and 5 give coefficients from multiple logistic regression between presence and absence of species and (C) SURROUNDING COVER and (D) TRUNK DIAMETER ( $\mathrm{n}=90$ trees). See Section 2.3. *, $\mathrm{P}<0.05$; **, $\mathrm{P}<0.01$; ***, $\mathrm{P}<0.001$. 
Table 4

Analysis of covariance between number of species occurrences of saproxylic beetles and (1) ORIGINAL CANOPY COVER (covariate) and (2) FOREST REGROWTH (factor) ${ }^{\mathrm{a}}$

\begin{tabular}{|c|c|c|c|c|c|}
\hline & \multicolumn{5}{|c|}{ ORIGINAL CANOPY COVER FOREST REGROWTH } \\
\hline Group & Mean $^{\mathrm{b}}$ & B & $\mathrm{P}$ & Diff. & $\mathrm{P}$ \\
\hline 1 & 35.3 & -2.92 & $\mathrm{NS}^{\mathrm{d}}$ & -3.89 & NS \\
\hline 2 & 28.9 & -3.75 & $* *$ & -4.22 & $*$ \\
\hline 3 & 21.0 & -2.50 & NS & -7.11 & $*$ \\
\hline 4 & 4.4 & -1.08 & NS & 1.67 & NS \\
\hline 5 & 8.2 & -0.08 & NS & -1.89 & NS \\
\hline 6 & 2.3 & -1.25 & $* *$ & -1.33 & NS \\
\hline Red-listed $^{\mathrm{c}}$ & 37.3 & -3.17 & NS & -8.22 & $* *$ \\
\hline Not red-listed & 62.7 & -8.42 & $*$ & -8.56 & NS \\
\hline Total & 100.1 & -11.58 & $*$ & -16.78 & $*$ \\
\hline
\end{tabular}

${ }^{\text {a }}$ Species divided into six groups: (1) Rotten wood in any part of the trunks, even on the outside. (2) Rotten wood in trunks, exclusively from the inside, in hollows. Not associated with animal nests. (3) Animal nests in tree hollows. (4) Fruiting bodies of saproxylic fungi. (5) Dead, dry wood in trunks. (6) Branches of old oaks.

${ }^{b}$ Mean=Mean number of species occurrences per plot (i.e. number of species per tree summed for each plot), $\mathrm{B}=$ coefficient, $\mathrm{P}=$ significance, Diff.=difference between plots with forest regrowth and plots still grazed in mean number of species occurrences. $n=18$.

${ }^{\mathrm{c}}$ Red-listed according to Ehnström et al. (1993).

${ }^{\mathrm{d}} \mathrm{NS}$, not significant; *, $\mathrm{P}<0.05$; **, $\mathrm{P}<0.01$. 
Table 5

Multiple linear regression between number of saproxylic beetle species per tree and (A)

SURROUNDING COVER and (B) TRUNK DIAMETER ${ }^{\mathrm{a}}$

\begin{tabular}{llllll} 
& \multicolumn{2}{l}{ SURROUNDING COVER $^{2}$} & \multicolumn{2}{l}{ TRUNK DIAMETER } \\
Group & Mean $^{\mathrm{b}}$ & $\mathrm{B}$ & $\mathrm{P}$ & $\mathrm{B}$ & $\mathrm{P}$ \\
1 & 7.06 & -0.63 & $\mathrm{NS}^{\mathrm{d}}$ & 1.23 & $\mathrm{NS}$ \\
2 & 5.78 & -0.51 & $\mathrm{NS}$ & 1.39 & $*$ \\
3 & 4.20 & -0.32 & $\mathrm{NS}$ & 0.49 & $\mathrm{NS}$ \\
4 & 0.88 & 0.37 & $* *$ & 0.71 & $* *$ \\
5 & 1.63 & -0.27 & $\mathrm{NS}$ & 0.03 & $\mathrm{NS}$ \\
6 & 0.47 & -0.26 & $* *$ & 0.06 & $\mathrm{NS}$ \\
Red-listed $^{\mathrm{c}}$ & 7.47 & -0.83 & $*$ & 1.09 & $\mathrm{NS}$ \\
Not red-listed & 12.54 & -0.78 & $\mathrm{NS}$ & 2.81 & $* *$ \\
Total $^{2}$ & 20.02 & -1.61 & $\mathrm{NS}$ & 3.90 & $*$
\end{tabular}

${ }^{\text {a }}$ Species divided into six groups: (1) Rotten wood in any part of the trunks, even on the outside. (2) Rotten wood in trunks, exclusively from the inside, in hollows. Not associated with animal nests. (3) Animal nests in tree hollows. (4) Fruiting bodies of saproxylic fungi. (5) Dead, dry wood in trunks. (6) Branches of old oaks.

${ }^{\mathrm{b}}$ Mean $=$ mean number of species per tree. $\mathrm{B}=$ coefficient, $\mathrm{P}=$ significance. $\mathrm{n}=90$.

${ }^{\mathrm{c}}$ Red-listed according to Ehnström et al. (1993).

${ }^{\mathrm{d}} \mathrm{NS}$, not significant; $*, \mathrm{P}<0.05 ; * * \mathrm{P}<0.01$.

(NOTE THAT THERE ARE ERRORS IN THE PUBLISHED VERSION OF THIS TABLE. THIS IS A CORRECTED VERSION) 
Table 6

Number of saproxylic beetle species per tree, with the trees divided into categories of different TRUNK DIAMETER and SURROUNDING COVER ${ }^{\mathrm{a}}$

\begin{tabular}{lccc}
\multicolumn{2}{l}{$\begin{array}{l}\text { Variable } \\
\text { TRUNK DIAMETER }\end{array}$} & Mean & S.D. \\
$<0.8 \mathrm{~m}$ & 22 & 17.1 & 4.8 \\
$0.8-1.0 \mathrm{~m}$ & 12 & 20.9 & 5.0 \\
$1.0-1.2 \mathrm{~m}$ & 25 & 20.3 & 6.7 \\
$1.2-1.4 \mathrm{~m}$ & 13 & 20.7 & 6.1 \\
$>1.4 \mathrm{~m}$ & 18 & 22.1 & 7.4 \\
SURROUNDING COVER & & \\
Free-standing & 21 & 23.8 & 5.3 \\
Half-open & 30 & 19.0 & 6.8 \\
Shaded & 39 & 18.7 & 5.7
\end{tabular}

${ }^{\mathrm{a}} \mathrm{n}=$ number of hollow oaks, Mean=mean number of species per tree, S.D.=standard deviation of number of species per tree. 
Table 7

Species preferring sun exposure and shade, according to Palm (1959) and the present study ${ }^{\mathrm{a}}$ This study

Sun Indifferent Shade

Palm (1959) Sun Anthrenus scrophulariae Agrilus sulcicollis

Hypebaeus flavipes Ampedus balteatus

Ampedus cardinalis

Ampedus hjorti

Anthrenus museorum

Phymatodes testaceus

Procraerus tibialis

Tillus elongatus

\begin{tabular}{|c|c|c|}
\hline Indifferent & $\begin{array}{l}\text { Conopalpus testaceus } \\
\text { Mycetochara linearis } \\
\text { Orchesia micans } \\
\text { Pentaphyllus testaceus } \\
\text { Tenebrio molitor } \\
\text { Trox scaber }\end{array}$ & Ptinus subpilosus \\
\hline
\end{tabular}

Shade Allecula morio

${ }^{a}$ Preferences according to this study are achieved from the statistical significant relations with SURROUNDING COVER. All species studied specifically in the present study are potentially included, except Cryptophagus micaceus, as it was not studied by Palm (1959). Species indifferent in both studies are excluded. 